\title{
An Empirical Analysis of Capital Adequacy in the Banking Sub-Sector of the Nigeria Economy
}

\author{
Samson Ogege(Corresponding author) \\ Department of Finance \\ University of Lagos, Lagos, Nigeria \\ Tel: 234-803-669-1036Ｅ-mail: ogegesamson@yahoo.com
}

Harley Tega Williams

Lagos Metropolitan Business School, Lagos, Nigeria

Tel: 234-803-481-6214Ｅ-mail: harleytega@yahoo.com

Apollos Emerah

Department of Banking and Finance

Bowen University, Iwo

E-mail: emera@gmail.com

Received: February 17, 2012

doi:10.5539/ijef.v4n5p208

\author{
Accepted: March 20, 2012 \\ Published: May 1, 2012 \\ URL: http://dx.doi.org/10.5539/ijef.v4n5p208
}

\begin{abstract}
The paper sets out to examine the impact of capital adequacy in the banking sub-sector and the growth of Nigeria economy. It specifically seeks to ascertain the effect of bank capital base and macroeconomic variables. Nigeria's data set from CBN statistical bulletin (2009) during the period 1980-2010 was used. It employed the error correction framework and co-integration techniques to test the relationship between bank capital base and macroeconomics variables. This implies that political stability may reduce financial distress and bankruptcy why foreign investment will affect Banks capital in most developing economy in the period of financial crisis. However, the study also establishes that there is a negative relationship between inflation and banks capital base as inflation erode banks capital in most developing economy. This simply means that Nigerian government should regulate investment policy why banks regulators should strive to keep inflation rate at a minimum level, if possible below $5 \%$ for them to be more efficient so as to be globally competitive.
\end{abstract}

Keywords: Capital adequacy, Macroeconomics variables, Global credit crunch

\section{Introduction}

One of the biggest achievements in the financial sector of the Nigeria economy in 2005 was the reform of the Banking Sector. It was an achievement via the Central bank of Nigeria increase in bank capital above 1000 percent. It was an exercise that resulted in the reduction of Nigeria motley group of mainly anemic 89 banks to 25 bigger, stronger and more resilient financial institutions. The reforms engineered a revolution in the financial services industry leading to an increase both in the quality of service and quantity of financial products available to Nigerians and to checkmate the capital adequacy of the banks.

Capital Adequacy can be percentage ratio of a financial institution's primary capital to its assets (loans and investments), used as a measure of its financial strength and stability. According to the Capital Adequacy Standard set by Bank for International Settlements (BIS), banks must have a primary capital base equal at least to eight percent of their assets: a bank that lends 12 dollars for every dollar of its capital is within the prescribed limits. However, the assessment of capital adequacy for precautionary purposes is problematic at best due to rapidly changing economic and financial services industry. Another role of capital is the fact that the viability of a bank depends to a critical extent upon public confidence. There is a strong public relation aspect to capital adequacy also. It is generally recognized that the availability of capital is neither a perfect indicator of the state of health of a bank nor a sufficient condition to ensure the maintenance of confidence by depositors and creditors, but no doubt, it represents a major element in 
shaping their perception of the solidity of an institution. Capital level is used by most regulators to restrict credit expansion. That explains why banks management are inspired to determine the correlation between variables like Total credit loan, Demand deposit, Inflation rate, Political instability, Money supply, Liquidity risk, Investment etc and Capital and hence indicate whether large capital are negatively or positively compel banks to meet the capital adequacy requirement or seek additional capital so as to meet their credit expansion target. By looking at banks role as a financial intermediaries, capital adequacy and macroeconomic variables have become a key indicator of a bank capital whereby inflation erodes banks capital in most developing countries. Indeed, several studies have found evidence that the development of the banking sector is related to economic growth. The importance of capital adequacy in the banking sub-sector of the Nigeria economic and financial development directs us to investigate which economic- macro or micro, banks ratios and balance sheet and institutional factors that give rise to a vibrant capital adequacy.

Therefore, the problem here is to use co-integration to determine whether there is a linear relationship between banks capital and macroeconomics variables and if there is, whether the degree of linearity is such that capital adequacy issues could be largely a matter of bank failure or business exigencies as opposed to the current flex of legal muscle by the regulatory authorities. Against this backdrop, the objectives of the study are to empirically investigate the determinants of capital adequacy with respect to economics variables. To analyze the various issues involved in capital adequacy debate. To examine the components of bank capital and bank consideration in selecting capital mix. To expound the diverse measurements of capital adequacy particularly the CAMELS. Furthermore, capital adequacy in the banking sector model is to permit forecasting of capital adequacy pattern, which is useful for both policy makers and the banking sector in general for formulating informed course of action.

In spite of the importance of banks as financial intermediaries, capital adequacy modeling has not been in the mainstream of econometric research into the financial sector in Nigeria. Analyses of the banking sector have so far focused on qualitative assessment of growth trends and sectoral behviour patterns in the industry. Discussion in those studies has, for instance, suggested a number of factors that may influence the failure pattern of banks, bank products and management. There has been no model designed to determine the relative impact of banks capital and macroeconomics variables and their possible linkages between the banking sector and the real sector of the economy. Since independence, no consensus has been reached by different Scholars as regards the determinants of capital adequacy with macroeconomics variables in Nigeria.

Opinion differs among experts in banking and finance as to what constitutes adequate capital but they all agree that it is an age long issue for which there do not seem to be any consensus in sight. Thus as noted by Nwankwo (1990), Adegbite (2010), the issue of what constitutes an adequate capital for banks has a long history. It is in fact, almost as old as banking itself.

Sanusi (2010) was even more satirical in answering the question of how much capital a bank needs to ensure the confidence of depositors, creditors, investors and regulators in a country of high inflation rate and economic instability, when he noted "that in banking and finance literature, this question is noted as the issue of capital adequacy. Anyone who knows the answer can gain instant notoriety in the banking, financial and regulatory communities.

However, the battle between the banks and regulatory authorities is centered after a prolonged period of recession and macro-economic instability. Hitherto, several studies have emphasized the importance of capital adequacy and there is need to review related studies in order to gain more understanding of the subject.

Mpuga (2002) argued that the inadequacy of minimum capital standards in accounting for risks in banks assets portfolio could be one of the major factors leading to bank failures. He studied the 1998-99 banking crisis in Uganda and how the new banking guidelines in Uganda was to increase bank solvency and capital adequacy by shifting their portfolio towards lower risk assets, in an effort to meet the new requirements

Yu Min-The(2006), defined the adequate capital for banks as the level at which the deposit insuring agency would just breakeven in guaranteeing the deposits of individual banks with premium the banks pay. An option of theoretical framework was employed in his study for measuring fair capital adequacy holdings for a sample of depository institutions in Taiwan, during 1985-1992. Except for the 1989, most banks in their sample proved to be inadequately capitalized so that capital infusion is required.

George \& Dimitrios (2004) applied non-parametric analytic technique (data envelopment analysis, DEA) in measuring the performances of the Greek banking sector with respect to capital adequacy. He proved that data envelopment analysis can be used as either an alternative or complement to ratio analysis for the evaluation of an organization's performance with attention to macroeconomics indicators. 
Morris, Alan \& Mukesh (2006) research studies examine the tendency for serial correlation in bank holding company profitability, finding significant evidence of reversion to the industry mean in profitability. The paper then considers the impact of mean reversion on the evaluation of post-merger performance of bank holding companies. The research concludes that when an adjustment is made for the mean reversion, post-merger results significantly exceed those of the industry in the first 5 years after the merger.

Robert (1997) estimated pre- and post-merger X-inefficiency in 348 mergers approved by the OCC in 1987/1988. Efficiency improved in only a small majority of mergers, and these gains were unrelated to the acquiring banks efficiency advantage over its targets. Efficiency gains were concentrated in mergers where acquiring banks made frequent acquisitions, suggesting the presence of experience effects.

Chol(2000), studied the credit crunch in the banking sector in Korea in year 1997, found the replacement of an old capital standards with risk based and macro economics based variables RBC \& MBC 1997, increased banks below the regulatory capital requirements from 0-14, and a number reduced to 7 in 1998 and the banks capital deficiency amounted to 59 percent of the total Korea asset in 1997.

Hassan (2008), mentioned that banks had been exposed to standby letters of credit (SLC) and off-balance sheet activities, which has become a major concern to regulators. This means that macroeconomic variables such as inflation play a greater role in the determinants of capital adequacy in most developing countries like Nigeria.

Ajayi (2008), The macroeconomic indicators (i.e. inflation and economic growth) are significant in both spread, bank capital adequacy and profit regressions. This may suggest that banks tend to not being profitable in inflationary environment. In addition, economic growth does not reflect any aspects of banking regulations and technology advance in the banking sector with require pressing attention.

\subsection{Research Methods}

This applies to the error correction methodology to a regression model based on the traditional determinants of capital adequacy in the banking sub-sector of the Nigeria economy distilled from the literature. The idea is to subject the variables to stationary test and subsequently remove the non- stationary trends by differencing before regressing. This removes the possibility of the so-called spurious regression. Any previous studies on the determinants of capital adequacy in the banking sub-sector of the Nigeria economy if there exist any in Nigeria may not have considered the problem of unit roots in the determinants of capital adequacy and macroeconomics variables. As a result, the econometric methodology used in those studies did not account for non-stationarity in the data. The analysis here is primarily based on Engle and Granger (1987), and Engle and Yoo (1987). The idea is to determine the order of integration of the variables, that is, we test whether they are stationary in their levels or whether they have to be differenced once or more before they become stationary. Testing for unit roots is carried out by using an Augmented Dickey-Fuller (ADF) test.

In order to account for the determinants of capital adequacy in the banking sub-sector of the Nigeria economy, the model for the study is hereby specified as follows:

\section{CAB $=$ f (TL, MS, DIR, INFL, DL, POL, ER, LQ, OPEN, INV)}

The above model is hereby written in log - linear form as:

(L) $\mathrm{CAB}=\mathrm{b}_{\mathrm{o}}+\mathrm{b}_{1} \mathrm{TCL}(\mathrm{L})+\mathrm{b}_{2} \mathrm{MS}(\mathrm{L})+\mathrm{b}_{3} \mathrm{DIR}(\mathrm{L})+\mathrm{b}_{4} \mathrm{INFL}(\mathrm{L})+\mathrm{b}_{5} \mathrm{DL}(\mathrm{L})+\mathrm{b}_{6} \mathrm{POL}(\mathrm{L})+\mathrm{b}_{7} \mathrm{ER}(\mathrm{L})+\mathrm{b}_{8} \mathrm{LQ}(\mathrm{L})+$ $b_{9} \mathrm{OPEN}+\mathrm{b}_{10} \mathrm{INV}+\mu_{\mathrm{t}} \ldots \ldots \ldots \ldots \ldots \ldots \ldots \ldots \ldots \ldots(1)$

apriori, $\mathrm{b}_{1}>0, \mathrm{~b}_{2}>0, \mathrm{~b}_{3}>0, \mathrm{~b}_{4}<0, \mathrm{~b}_{5}>0, \mathrm{~b}_{6}<0, \mathrm{~b}_{7}>0, \mathrm{~b}_{8}>0, \mathrm{~b}_{9}>0, \mathrm{~b}_{10}>0$

Where:

\begin{tabular}{|c|c|c|}
\hline$* \mathrm{CAB}$ & $=$ & CAPITAL ADEQUACY BASE \\
\hline TL & $=$ & TOTAL LOANS. \\
\hline MS & $=$ & MONEY SUPPLY \\
\hline DIR & $=$ & DOMESTIC INTEREST RATE (REAL) \\
\hline INFL & $=$ & INFLATION RATE \\
\hline DL & $=$ & DEMAND DEPOSIT \\
\hline POL & $=$ & POLITICAL INSTABILITY DUMMY = 1 MILITARY \\
\hline & & REGIME AND TURBULENT YEARS, 0 OTHERWISE \\
\hline ER & $=$ & EXCHANGE RATE \\
\hline
\end{tabular}




\section{LQR $=\quad$ LIQUIDITY RISK \\ OPEN $=$ OPENNESS OF THE ECONOMY (TOTAL TRADE /GDP RATIO) \\ INV $=\quad$ INVESTMENT (proxied by long US interest rate)}

Capital adequacy being the dependent variable is the total asset of banks deflated by total number of capitalize banks operating in the economy while the independent variables such as demand deposit is total deposits including private and public, investment include both local and foreign direct investment while others variables includes total loans, money supply and interest rate (real), exchange rate, inflation rate (nominal), political instability -including civilian and military regime. $\mathrm{U}_{\mathrm{t}}=$ Captures other variable not included in the model and it takes care of other factors that cannot be observed or computed due to lack of data. $U_{t}$ is referred to as error term, residual or stochastic term.

"The Data Analysis technique consists of an approach designed to capture the long-run relationship between the dependent and independent variables, while avoiding spurious influences. This is the co-integration and error correction techniques which have received prominent attention in literature (see Adam, 1992, Engle and Granger, 1987, Gilbert, 1986, Hendry and Richard 1983 and Thomas 1993).

The aim of the new framework was to ascertain the time characteristics of data, overcome the problems of spurious correlation often associated with none — stationary time series data, and generated long — run variable relationship simultaneously. Within this dispensation, an important starting point for research is an assessment of the degree of integration of the relevant variables and to check whether they are co-integrated or not. It should be noted that an important issue in econometrics is the need to integrate short-run dynamics with long-run equilibrium. The analysis of short-run dynamics is often done by first eliminating trends in the variables, usually by differencing. The theory of co-integration development in Granger (1981) and elaborated in Engle and Granger (1987) addressed this issue of integrating short-run dynamics with long-run equilibrium.

Similarly, it is important to note that the usual starting point of ECM modeling is to assess the order of integration of both the dependent and independent variables in the model. The order of integration ascertains the number of time a variable will be differentiated to arrive at stationary. Dickey-fuller (DF), Augmented Dickey-Fuller (ADF) and Sargan - Rhargava Durban-Watson (SRDW) are the widely used test for stationary for both individual time series and residual from OLS regressions. Co-integration is based on the properties of the residuals from regression analysis when the series are individually non-stationary.

The original co integration regression is specified as follows:

$$
\mathrm{A}_{\mathrm{t}}=\alpha_{0}+\alpha_{1} \beta_{t}+\ell_{t}
$$

Where A represents the dependent variables, $\beta$ stands for the independent variable, and $\ell \mathrm{e}$ is the random error term. $\alpha_{0}$ and $\alpha_{1}$ are intercept and slope coefficients respectively. To include the possibility of bi-directional causality, the reverse specification of equation 1 is considered.

To provide a more defensive answer to the non-stationarity in each time series, the Dickey-Fuller (1979) regression is estimated as follows for a unit root:

$$
\Delta \mathrm{e}_{\mathrm{t}}=-\lambda \mathrm{e}_{\mathrm{t}-1}+\mathrm{w}_{\mathrm{t}}
$$

If $\mathrm{X}$ Equals zero e is non-stationary. As a result, $\mathrm{A}$ and $\mathrm{B}$ are not co-integrated. In other words, if $\mathrm{X}$ is significantly different from zero A and B are found integrated individually.

Given the inherent weakness of the root test to distinguish between the null and the alternative hypothesis, it is desirable that the Augmented Dickey-Fuller (ADF) (1981) test be applied. The desirability is warranted because it corrects for any serial correlation by incorporating logged changes of the residuals. To be co-integrated, both A and B must have the same order of integration (Eagle and Granger, 1987 and Granger, 1986).

The ADF regression is specified as follows:

$$
\Delta \ell_{t}=\beta_{o} \ell_{t-1}+\sum_{i=i}^{m} \beta_{j} \Delta \ell_{t-1}+\mu_{t}
$$

Where $\Delta$ is the first different operator and $\mu_{\mathrm{t}}$ is the new randori ${ }^{2}$ error term. $\mathrm{M}$ is the optimum number of lags needed to obtain "white noise". This is approximated when the DW value approaches 2.0 numerically. The null hypothesis of non co-integration is rejected, if the estimated ADF statistics is found to be larger than its critical value at 1 or 5 or 10 per cent level of significance.

if $A_{t}$ and $B_{t}$ are found to be co-integrated, then there must exist an associated error-correlation Model (ECM), according to Engle and Granger (1987). The usual ECM may take the following form: 


$$
\Delta \mathrm{G}_{\mathrm{t}}=\sigma_{\mathrm{o}} \mathrm{e}_{\mathrm{t}-1}+\sum_{j=1}^{T} \sigma_{1} \Delta \mathrm{A}_{\mathrm{t}-\mathrm{j}}+\sum_{j=1}^{T} \theta_{j} \Delta \mathrm{B}_{\mathrm{t}-\mathrm{j}}+\mathrm{V}_{\mathrm{t}}
$$

Where $\Delta$ denotes the different operator $\mathrm{e}_{\mathrm{t}-1}$ is the error correction term, $\mathrm{T}$ is the number of lags necessary to obtain white noise and $V_{t}$ is another random disturbance term. If $\sigma_{o} e_{t-1}$ is significantly different from zero, then $A$ and $B$ have long-Run relationship. The error-correction term $\left(\mathrm{e}_{\mathrm{t}-\mathrm{I}}\right)$ depicts the extent of disequilibrium between $\mathrm{A}$ and $\mathrm{B}$ The ECM, reveals further that the change in $A_{t}$ not only depends on lagged changes in $B_{t}$, but also on its own lagged changes. It is appealing due to its ability to induce flexibility by combining the short-run and long-run dynamics in a unified system. Also, the estimates of the parameters of the ECM are generally consistent and efficient (Ilendry and Richard, 1983).

Insert Table 1, Table 2, Table 3, Table 4 \& Table 5 Here

\subsubsection{Analysis Result}

It was discovered through this study that, there were long run relationship between Exchange rate, Inflation rate, Political Instability, and Money Supply. Also, all the variables employed in this study were all stationary at their first difference except rate of real domestic interest rate and return on investment that were stationary at their levels. There are some major findings that this study has revealed.

These findings include:

1. From the result of the study, one could see that money supply is an important determinant of capital adequacy base in Nigeria. Its high coefficient and very strong level of significance even at one percent suggests that increase in Money leads to an increase in Bank capital base. The increase in CAB could also have a feedback effect on economic growth.

2. The real domestic interest rate is also an important determinant of Bank capital adequacy base in Nigeria, since it is statistically significant at one percent level of significance, although it is inversely related to CAB which suggests that the rise in real cost of capital, informed by an increase in real interest rate would tend to dampen CAB especially those requiring some degrees of domestic capital.

3. The real exchange rate is another significant determinant of CAB in Nigeria. Although, the coefficient is not as expected, but existing literature emphasized an inverse relationship which implies that an increase, in the real exchange rate will reduce the flow of Foreign direct investment and so reducing CAB in Nigeria and vice versa.

4. The return on investment in the rest of the world proxied by long- run US interest rate is not a strong or significant determinant of $\mathrm{CAB}$ in Nigeria while Inflation rate erodes $\mathrm{CAB}$ but existing literature has shown that foreign direct investment has negative impact in developing economy during period of financial crisis.

5. The Deposit liabilities and liquidity risk variables are not correctly signed and are not statistically significant but may increase $\mathrm{CAB}$ via increase in money supply.

6. As can been seen, the coefficients that appears on the INV have his theoretically predicted signs and in general are statistically significant. The, result indicated that Investment increases CAB via inflow of Foreign direct investments into Nigeria.

7. Lastly, the political dummy used as proxy for political instability was appropriately signed indicating that intermittent coup d'etat and incessant political upheaval may serve to scare away potential foreign investors thereby, reducing $\mathrm{CAB}$ in Nigeria.

The aim of this empirical study is to investigate the determinants of capital adequacy patterns in the Banking sub-sector in Nigeria. The study applied the Error Correction Model (ECM) and found empirical support for some conjectures made in the literatures. Given the importance of Capital adequacy in any economy and the likely economic effects on banks' capital on growth and development, it becomes expedient to examine how Capital adequacy in Nigeria can better be improved if attention is given to some macroeconomic variables.

\section{References}

Adam, C. S. (1992). Recent Developments in Econometric Methods: An Application to the Demand for Money in Kenya. Economic Research Consortium Special, Paper 15.

Alashi S.O. (2002). Banking Crisis: Causes, Early Warning Signals and resolutions in CBN. Enhancing Financial Sector Soundness in Nigeria. (Abuja)..

Ammer. C., \& Ammer. D. (1997). Dictionary of Business and Economics, London, Macmillan Publishing Company. 
Babble, D. F. (1981). Inflation and other macroeconomics variables in Brazil. pp.115-35. Journal of Risk and Insurance, 48.

Basel Committee on Banking Supervision. (2003). Overview of the New Capital Accord. Worldwide. [Online] Available: http://www.bis.org/bcbs/cp3part1.pdf`

Catalan et al. (2000). Contractual Savings or Stock Market Development: Which Leads? World bank, Financial Sector Development Department. Washington, D.C. Policy Research Working Paper 2421.

CBN. (2010). Central Bank of Nigeria Communiqué. No 73 of the Monetary policy committee Meeting. Nov 22-23.

Dickey, O.A., \& Fuller W. A. (1981). 'Likelihood Ratio Statistic for Auto-Regression Times Series with a Unit Root. pp 157-171. Econometrical, Vol. 4.

Ekpo, A. H (1997). Foreign Direct Investment in Nigeria: Evidence from Time Series Data. CBN Economic and Financial Review, 35(1), 31-46

Gujarati, D. N., \& Porter, D. C. (2009). Basic Econometrics. (4th Ed.). Published by McGraw-Hill. (Chapter $4,6,8,9)$.

Impavido et al. (2000). Contractual Savings, Stock, and Asset Markets Policy Research Working Paper 2490. World Bank, Financial Sector Development Department, Washington D. C.

Koutsoyiannis, A. (2003). Theory of Econometrics. (2 Ed.). Macmillan Publication. (Chapter 4,5,7,8,10,11)..

Muthrava, D.M. (2009). Capital Adequacy \& the Performance of Commercial Banks. pp 29-54. The International Journals of Applied Economics and Finance, 3(6.

Nnanna, O. J. (2003). Today's Banking Risks And Current Regulatory and Supervisory Framework. CBN bullion, 6(3), 89-102.

Noor M. A. (2004). Determinants Adequacy Ratio in Jordanian Banks. International Journal of Business and Management, 5(2), 31-46.

Oluba, M. (2010). Feedback on the CBN's Four Pillar Based Financial System Reforms in the Frontier Post, $C B N$ bullion, 2(4), 18-32.

Park R. E. (1966). Estimation with Heteroscedasticity Error Terms. Econometrical, 34(4), 888. http://dx.doi.org/10.2307/1910108

Rama, M. (1990). Empirical investment Equation in Developing Countries Policy, planning and Research Working Papers Series 563, World Bank, Washington D. C.

Reint Groop, \& Florian Heider. (2009). Determinants of Banks Capital Structure. PhD thesis. \{Online\} Available at http://ideas.repec.org/p/ecb/ecbwps/20091096.html.

Sammy, B. N. (2003). The Determinants of the Tunisian Banking Industry Profitability Panel Evidence. International journal of business and management, 5(2), 106-121

Sanusi, L. S. (2010). Evolving Financial Landscape: Strategies for Economic Resilience: Keynote Address presented at the $4^{\text {th }}$ Annual Banking and Finance Conference of the Chartered Institute of Bankers of Nigeria. Abuja September, pp23-24.

Thomas, R. C. (1993). Introductory Econometrics, theory and Applications. (2 Ed.). Longman Economic Series London and New York.

Thorsten B., \& Ian W. (2003). Economic Demography and Institutional Determinants Across Countries World Bank Economic Review, 17(1), 51-88. http://dx.doi.org/10.1093/wber/lhg011

Viral et al. (2009). Dividends and Banks Capital in the Financial Crisis of 2007-2009. \{Online\} Available at http://www.plosone.org/article/info:doi\%2F10.1371\%2Fjournal.pone.0007370

Zenith Bank. (2008). SECs Code of Corporate Governances in Nigeria. Zenith Bank Quarterly report. April 2. 
Table 1. Stationary Test

\begin{tabular}{|l|l|l|}
\hline Variables & ADF Test & Order of Integration \\
\hline Log CAD & $0.04925(-29969)$ & $1(1)$ \\
\hline Log CAD & $-3.7333(-3.0114)$ & $1(0)$ \\
\hline Log INV & $-3.6876(-2.9798)$ & $1(0)$ \\
\hline Log ER & $-2.0299(-2.9798)$ & $1(1)$ \\
\hline A Log ER & $-3.5063(-2.9850)$ & $1(0)$ \\
\hline Log DIR & $-4.2833(-2.9798)$ & $1(0)$ \\
\hline Log INV & $-3.3697(-2.9798)$ & $1(0)$ \\
\hline Log INFL & $-1.3068(-2.9969)$ & $1(1)$ \\
\hline A Log INFL & $-40706(-3.0038)$ & $1(0)$ \\
\hline Log OPEN & $0.8224(-2.9798)$ & $1(1)$ \\
\hline A Log OPEN & $-4.1436(-2.9850)$ & $1(0)$ \\
\hline Log MS & $-1.1022(-2.9798)$ & $1(1)$ \\
\hline A Log MS & $-3.0994(-2.9850)$ & $1(0)$ \\
\hline
\end{tabular}

Source: Authors' computation (2012)

Table 2. Johansen Co-integration Test Results

Sample: 1980 - 2010

Series: Log CAB, Log ER, Log INFL, Log OPEN, Log MS

\begin{tabular}{|l|l|l|l|l|}
\hline Eigen value & Likelihood Ratio & $5 \%$ & $1 \%$ & Hypothesized \\
\hline & & Critical & Critical & No. of CE(s) \\
\hline & & Value & Value & \\
\hline 0.84 & 114.3228 & 94.15 & 103.18 & None** \\
\hline
\end{tabular}

Note:* $\left.{ }^{* *}\right)$ ( denotes rejection of the hypothesis at $5 \%(1 \%)$ significance level.

L. R. test indicates 2 co-integration equation(s) at 5\% significance level.

Lags interval: 1 to 1

Source: Authors' computation (2012)

Table 3. Long-run Capital Adequacy Determinants Model Estimates

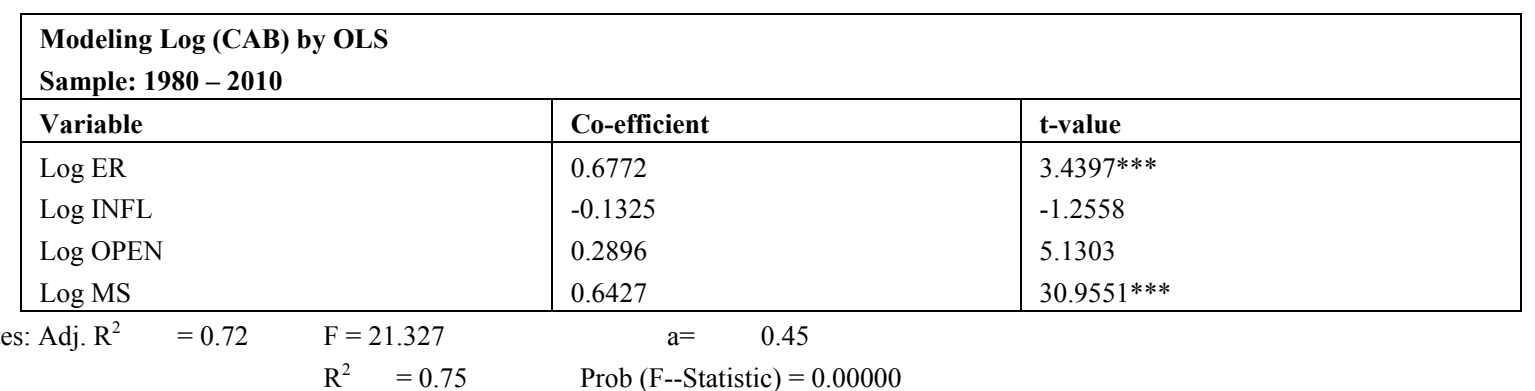

$\mathrm{Dw}=1.87 \quad$ Schwarz information criterion 1.561

* Significant at $1 \%$ Level

** Significant at $5 \%$ Level

*** Significant at $10 \%$ Level

a $=$ S. E. of regression

Source: Authors' computation (2012) 
Table 4. Short-run over - parameterized Capital Adequacy Determinants Model

Model Estimates Log (CAB) by OLS

Sample: $1980-2010$

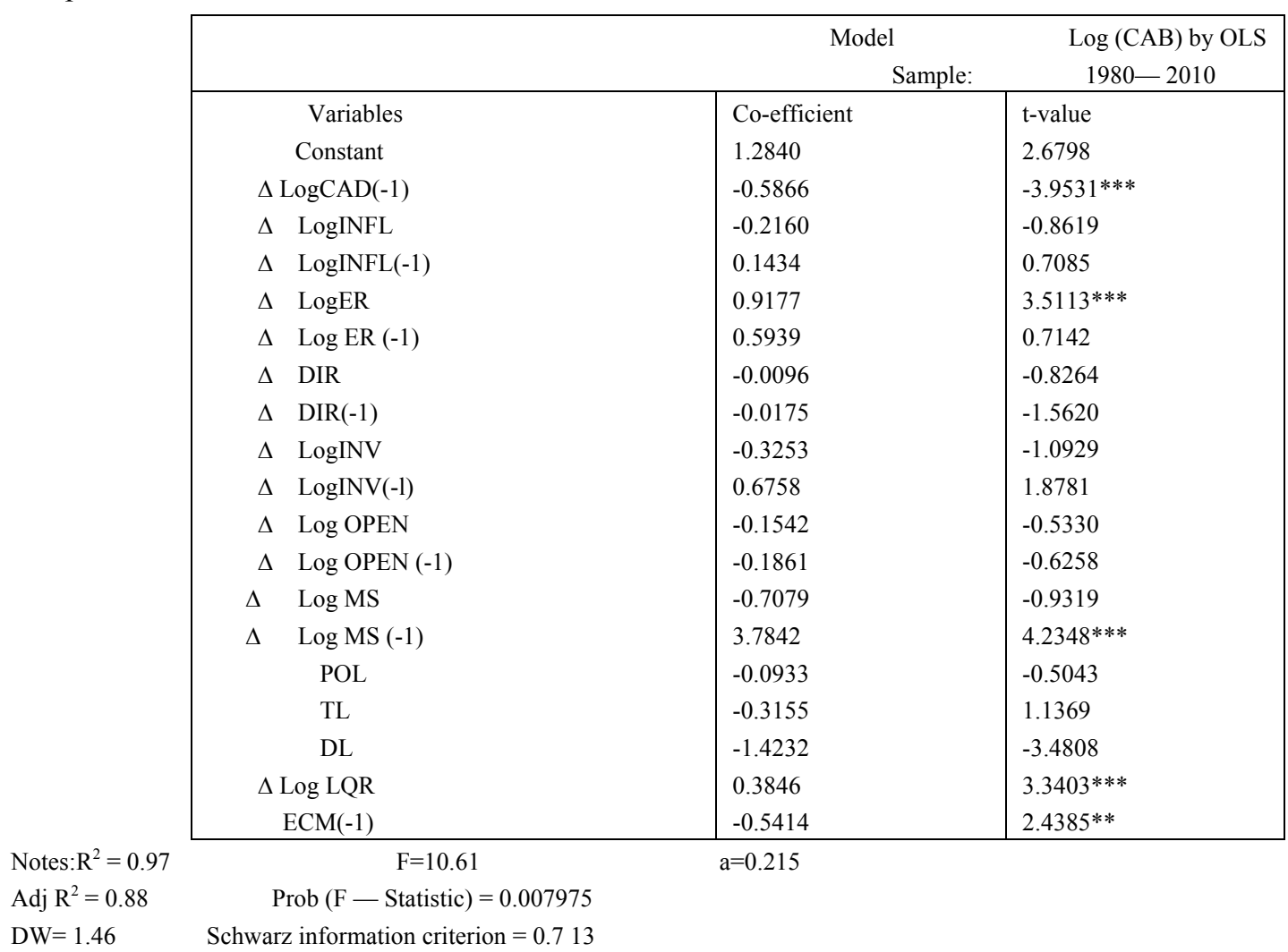

Source: Authors' computation (2012)

Table 5. Short-run Parsimonious Model Estimates

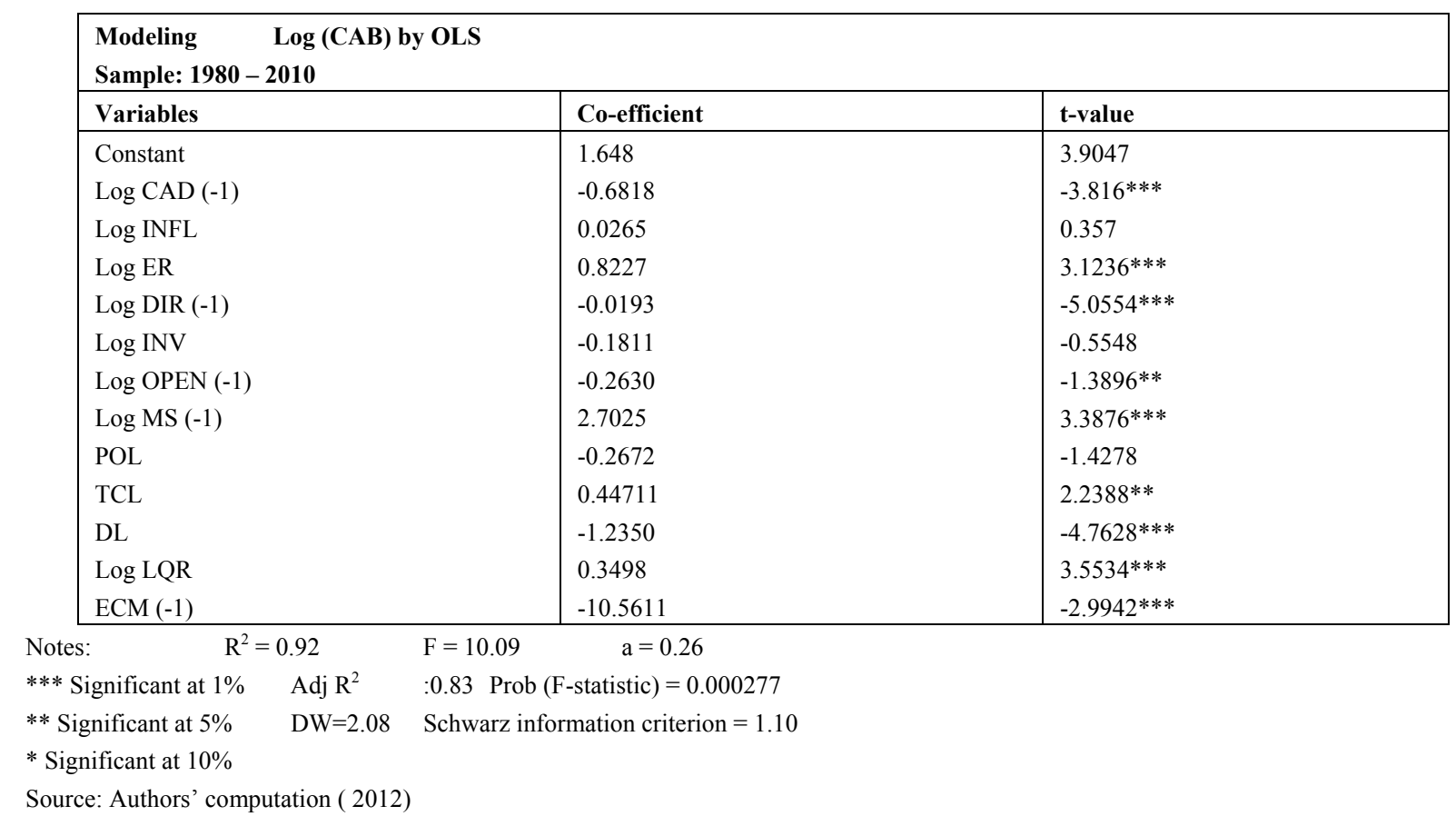

